\title{
CAUSATION, ECONOMISTS, AND THE DINOSAUR: A RESPONSE TO PROFESSOR DRAY
}

\author{
JEROME M. CulP*
}

\begin{abstract}
Now in the case of all other scourges sent from Heaven some explanation of a cause might be given by daring men, such as the many theories propounded by those who are clever in these matters; for they love to conjure up causes which are absolutely incomprehensible to man, and to fabricate outlandish theories of natural philosophy, knowing well that they are saying nothing sound, but considering it sufficient for them, if they completely deceive by their argument some of those whom they meet and persuade them to their view.
\end{abstract}

\section{INTRODUCTION}

Dinosaurs become extinct, individuals are injured by drunken drivers, and Mexico fails to avoid war with the United States-all of these are situations that are produced by some elemental causal forces. In general, the similarity of the causal questions at issue in these cases is ignored. Scientists tend to view their scientific causal inquiry in the dinosaur example as fundamentally different from the causal inquiry in the legal setting. This comment suggests that it is not possible for a scientist to ask, "What caused the dinosaur to become extinct?" or a judge to ask, "What caused an individual to be injured by a drunk driver in an automobile accident?" or a historian to ask, "What caused Mexico to fail to avoid war with the United States?" without raising and addressing a series of very similar questions. Ultimately, in all of these cases the investigator must ask what caused the event. This comment begins a discussion of these common causal questions in the context of the legal discussion of causation.

Generations of legal scholars, judges and legislators have unsuccessfully struggled with the idea of causation. Hart and Honoré in their book Causation in the $L a w^{2}$ have been among the most influential interpreters of the use and

Copyright $\odot 1986$ by Law and Contemporary Problems

- Associate Professor of Law, Duke University Law School. I would gratefully like to acknowledge the support of the Cannon Trust which helped to provide release time to complete this article, and the able assistance of two students, David Berger and Douglas Christensen. In addition, I would like to thank my colleagues, George Christie, David Lange, Richard Schmalbeck, and Christopher Schroeder for their comments. Any remaining errors are, of course, my responsibility.

1. R. Gottfried, The Black Death: Natural and Human Disaster in Medieval Europe 10 (1983) (quoting a description of the causes of the Black Death by Procopius, History OF THE WARS I (H. B. Dewing ed. 1914)).

2. H.L.A. Hart \& A. Honoré, Causation in the Law (2d ed. 1985) [hereinafter cited as H.L.A. HART \& A. Honoré]. In his article, Professor Dray also cites the original edition of Hart and 
abuse of causation in determining responsibility in legal disputes. Professor Dray has noted the contradictions and confusion in the description of causation by Hart and Honoré. ${ }^{3}$ Much of this confusion stems from Hart and Honorés use of the notions of attributive and explanatory causation and the use of cause and mere condition to explain the idea of responsibility. Professor Dray argues that Hart and Honoré fail to define a workable dichotomy between explanatory and attributive causes.

Part of Professor Dray's difficulty with Hart and Honoré's concepts is the elusiveness of their definitions. This elusiveness is traceable to the failure of Hart and Honoré clearly to define the goals of the causal inquiry and the entity that is to determine causation. Once the causal goal and the causal decision maker are defined, most of Professor Dray's concerns collapse into other, or at least more familiar, complexities. Defining the causal goal and the causal decision maker has the additional advantage of highlighting and contrasting Hart and Honoré's concerns about the assignment of responsibility.

The traditional notion of cause as described by Hart and Honoré becomes most significant when it is contrasted with the discussions of causation found in the extensive literature of the proponents of law and economics. The acceptance of the economists' perspective on causation has contributed significantly to the confusion of the courts and commentators about causation. ${ }^{4}$ The economists' contribution to causation is to increase the number and kind of issues that causal decision makers-courts, legislatures, and administrative agencies-use in allocating liability in legal situations. Essentially, economists argue that causal decision makers ought to use factors that impact economic efficiency when they allocate liability. ${ }^{5}$ In the economists' world, the traditional notions of causation do not exist. By examining the views of the proponents of law and economics, this comment will demonstrate the usefulness of Hart and Honoré's distinctions between causes and conditions, and between attributive and explanatory causes.

The economists who have written about causation have adopted a view Hart and Honoré call causal minimalism. ${ }^{6}$ The only concern of causal minimalists is the way in which something contributes to the instrumental

Honoré's book, H.L.A. Hart \& A. Honoré, Causation in THe Law (1959). Hart and Honoré's basic arguments about explanatory and attributive causes, and the distinction between causes and conditions are essentially unaltered from the original edition.

3. Dray, Causal Judgment in Attributive and Explanatory Contexts, Law \& Contemp. Probs., Summer 1986 , at 13 .

4. See, e.g., Union Oil Co. v. Oppen, 501 F.2d 558 (9th Cir. 1974). In Evra Corp. v. Swiss Bank, 673 F.2d 951 (7th Cir. 1982) Judge Posner attempts to apply the economic perspective to causal issues using the Learned Hand formula. For an explanation of the Hand formula, see infra note 26 and accompanying text. See generally Borgo, Causal Paradigms in Tort Law, 8 J. Legal Stud. 419 (1979); Kaye \& Aickin, $A$ Comment on Causal Apportionment, 13 J. Legal STud. 191 (1984); Landes \& Posner, Causation in Tort Law: An Economic Approach, 12 J. Legal Stud. 109 (1983); Rizzo \& Arnold, Causal Apportionment in the Law of Torts: An Economic Theory, 80 Colum. L. Rev. 1399 (1980); Shavell, An Analysis of Causation and the Scope of Liability in the Law of Torts, 9 J. Legal Stud. 463 (1980).

5. See H.L.A. HaRT \& A. Honoré, supra note 2, at lxvii-lxxvii; see also infra section III

6. H.L.A. Hart \& A. Honoré, supra note 2, at Ixviii. 
goal of achieving economic efficiency or social welfare maximization. Within this perspective, causal goals and causal decision makers are clearly defined. Causal decision makers are simply those individuals or institutions who have the duty of determining causation, assigning responsibility, and allocating liability in order to achieve the chosen instrumental goal. For economists, that goal is economic efficiency. With respect to historical or biological questions, the historian or the biologist is the causal decision maker. They are the individuals who investigate the data and determine what events are causally related to other historical or biological events. With respect to legal questions, the causal decision maker is the judge, jury, administrative agency, or legislature assigned the task of finding individuals liable for their actions. Some situations involve more than one causal decision maker. For example, in the case of a worker injured in an industrial accident, the administrator of the workers' compensation act, the court (in resolving any surviving common law questions), and the legislature (in enacting legislation making some employers criminally liable) are all causal decision makers.

Defining causal goals is slightly more difficult than defining causal decision makers. Causal goals are those goals that decision makers use in determining causation, assigning responsibility, and allocating liability. For example, the cliometrician attempts to explain historical trends through the use of economic and social statistics, and the intellectual paradigms of cliometrics. The intellectual historian's goal is to explain how earlier ideas have influenced later thought. Among judges, legislators, and administrators, the causal goal varies. They sometimes attempt to maximize wealth or social welfare and other times attempt to achieve corrective justice. For example, when a drunken driver injures an innocent third party, judges who emphasize social welfare maximization would focus on different issues than those that emphasize individual responsibility. By altering their goals, causal decision makers will significantly influence the outcome of their causal determinations. The definition of causal goals is partially tautological in that some of the complexity and confusion of defining causation is incorporated in the goals chosen. For example, the cliometrician is not seeking simply to find any set of facts that explain a historical event, but those facts that can be seen as causing the succeeding historical events. The causal minimalist, on the other hand, defines causation in terms of the instrumental goals of economic efficiency or social welfare maximization.

Section II of this comment briefly discusses the factors that allegedly contributed to the extinction of dinosaurs. It then shows that the application of Hart and Honoré's analysis to the dinosaur question yields reasonable and interpretable results. Section III demonstrates that, by applying the causal views of several proponents of economic theory to the dinosaur hypothetical, the proponents of law and economics are in different ways causally myopic. ${ }^{7}$

7. The extinction of the dinosaurs was chosen as an example of a causal inquiry for two reasons. Hart and Honoré and many others who have written on causation, including Dray, have argued that there is a common theme in the discussion of causation that runs through areas as 
Coase and Calabresi, the early proponents of the law and economics perspective, do not ackknowledge causes in their analysis. They view the causal question as essentially an explanatory inquiry. Causation does not exist, and everything that purports to be causally related to a subsequent event or state of affairs is an explanatory condition. Posner and the later economic proponents see everything as an attributive cause. For them, all causal questions have simply been collapsed into attributive questions. Section IV uses the example of the changing tort liability of the social host to illustrate the difficulty with the position of both contingents of economic thought. This comment concludes by arguing that the causal myopia of the economists effectively limits the kinds of answers they can obtain when pursuing questions about legal responsibility and, consequently, will show the importance of Hart and Honoré's causal distinctions.

II

\section{Causes, Conditions, and Dinosaurs}

There is a debate among scientists about what caused the dinosaurs' extinction. Scientists use causal language to explain the various forces that altered the status quo, thereby causing the dinosaurs' extinction. ${ }^{8}$ Some have argued that the dinosaurs died as a result of great climatic changes. Within this explanation, two theories have been advanced. Some believe that a meteor or comet hit the earth and created a kind of nuclear winter from which the dinosaurs were unable to escape. ${ }^{9}$ Others believe that other cyclical climatic changes were too drastic for the dinosaur to survive. ${ }^{10}$ Another explanation attributes the dinosaurs' extinction to the emergence of mammals who ate dinosaur eggs. ${ }^{11}$ Still other scientists contend that the inability of the dinosaur to survive was a product of the inability of dinosaur genes to adapt quickly enough to changed circumstances. ${ }^{12}$ An economist might consider

diverse as history and law. To the extent there is a common theme it is important to understand how the economists' views would be applied outside the legal framework. In addition, much of the conflict in the literature on causation concerns disagreements about the substantive outcome of the causal questions. The causal inquiry into the extinction of dinosaurs removes these substantive issues from the debate about causation so that it is possible to focus on the issues about which the economists differ from Hart and Honoré.

8. See, e.g., McLean, A Terminal Mesozoic "Greenhouse": Lessons from the Past, 201 Sci. 401, 401 (1978) ("extinctions ... may have been caused in part by a decreasing equability of the climate") (emphasis added); Officer \& Drake, Terminal Cretaceous Environmental Events, 227 ScI. 1161, 1161 (1985) ("Although there is general agreement that the end of Cretaceous time is marked by one of the most significant faunal and floral transitions in the Phanerozoic record, there is less agreement about the causes. ... The causes of biostraitgraphic changes are important not only in understanding the physical development of the earth but also biological evolution.") (emphasis added).

9. Hsu, Terrestrial Catastrophe Caused by Cometary Impact at the End of Cretaceous, 285 NATURE 201 (1980).

10. See Alvarez, Alvarez, Asaro \& Michel, Extraterrestrial Cause for Cretaceous-Tertiary Extinction, 208 ScI. 1095 (1980) (alternative causes of extinction of dinosaurs are listed and discussed, including climatic conditions due to random or a cyclical coincidence of causative factors).

11. Jepson, Riddles of the Terrible Lizard, AM. Scientist, June 1964, at 52, 52.

12. "Such a selective pattern [of extinction] seems to indicate an environmental stress that some organisms were adapted to meet and others were not." McLean, supra note 8, at 401. 
the adaptability of genes as a function of how risk-averse the dinosaur is. Risk-averse dinosaur genes would permit more diverse reactions to climatic changes by, for example, providing for greater variation in the size of dinosaur offspring. A final explanation, also attributable to 'the economists perspective,' views the dinosaurs' extinction as a product of their level of propagation and food consumption. From this perspective, the very act of living increased the likelihood of the dinosaurs' extinction.

Applying Hart and Honoré's distinction between causes and mere conditions to the dinosaur extinction problem helps illustrate the differences among approaches to causal analysis. Hart and Honoré argue that it is possible to distinguish between causes and mere conditions based on three factors. ${ }^{3}$ First, an event or occurrence is a cause if it is abnormal and, therefore, distinguishable from the normal conditions that surround existing circumstances. ${ }^{14}$ Second, an event or occurrence is a cause and not a mere condition if an individual has voluntarily produced it. ${ }^{15}$ Third, an event or occurrence is a cause and not a mere condition if it is in close temporal proximity to the event. ${ }^{16}$

Applying Hart and Honoré's factors to the dinosaur causal nexus makes clear that neither the dinosaurs' participation nor the failure of dinosaurs or their genes to respond to climatic changes are causal factors. The reason is that neither are abnormal conditions in Hart and Honoré's sense. The levels of dinosaur propogation and food consumption are not causes because these levels (assuming they did not change as a result of climatic forces) are part of

13. H.L.A. HART \& A. Honoré, supra note 2, at 67-81; see Dray, supra note 3, at 14-15.

The Massachusetts courts in particular have used the distinction between mere condition and cause.

The defense rests principally upon the fact that the plaintiff was intoxicated, and was incapable of caring for himself after he was taken from the train, and therefore was not in the exercise of due care. If his voluntary intoxication was a direct and proximate cause of the injury, he cannot recover. The plaintiff contends that it was not a cause, but a mere condition, well known to the defendant's servants, and that their act was the direct and proximate cause of the injury, with which no other act or omission had any causal connection. The distinction here referred to is well recognized in law. Negligence of a plaintiff at the time of an injury caused by the negligence of another is no bar to his recovery from the other, unless it was a direct, contributing cause to the injury, as distinguished from a mere condition, in the absence of which the injury would not have occurred.

Black v. New York, N.H. \& H.R. Co., 193 Mass. 448, 450, 79 N.E. 797, 798 (1907).

The best minds often differ upon the question whether, in a given case, illegal conduct of a plaintiff was a direct and proximate cause contributing with others to his injury, or was a mere condition of it .... But, even in that case, external causes may have been so exclusive in their operation, and so free from any relation to the position of the vehicle, as to have left that a mere condition, without agency in producing the result . . . .

Newcomb v. Boston Protective Dep't, 146 Mass. 596, 602, 604, 16 N.E. 555, 558-59 (1888).

In Davies $v$. Mann . . . the plaintiff negligently left his donkey in a public street, with his fore legs fettered, and the defendant drove over him carelessly. It was held that the plaintiff could recover, notwithstanding his negligence, it being a condition, but not a contributing cause, of his injury.

Marble v. Ross, 129 Mass. 44, 48 (1878) (citation omitted).

14. H.L.A. HART \& A. HonorÉ, supra note 2, at 67-68; see Dray supra note 3, at 14.

15. H.L.A. HART \& A. HonORÉ, supra note 2, at 60-72; see Dray supra note 3, at 14.

16. H.L.A. HART \& A. HonORÉ, supra note 2, at 70-74; see Dray supra note 3, at 14. 
the ordinary functioning of the organism. It is difficult to view normal procreation and eating as being voluntary in any but the narrowest sense. Similarly, dinosaur genes are immutable and, therefore, cannot be causes. Certainly, dinosaurs had the option of expiring by not reproducing or consuming vegetation, but such a restricted view of voluntary action is inconsistent with the conventional moral notion that life-preserving activities are not voluntary.

Hart and Honoré would conclude that climatic conditions, either the meteors or the abnormal seasonal changes, caused the dinosaurs' extinction. The climatic changes that led to the demise of dinosaurs were abnormal for the time period in which the dinosaurs had developed. If it took the dinosaur 50,000 years to develop as a species and during that time period there was not a meteor shower of sufficient intensity to impact the dinosaur ecology, then with respect to the dinosaurs' extinction the meteor is a cause. It is possible to argue that there is always a small probability that meteors will strike the earth with sufficient severity to create a kind of nuclear winter. If one accepts this position, the meteor would not be viewed as abnormal. This perspective, however, is outside Hart and Honoré's causal time frame. They would argue that the explanatory causes of the dinosaurs' extinction were the climatic changes that produced abnormal weather. A scientist trying to allocate causal responsibility between the two theories of climatic changes by applying Hart and Honoré's principles would have the difficult task of determining which theory was correct.

The theory that egg-eating mammals caused, in Hart and Honoré's terms, the demise of dinosaurs, is also based on the identification of a cause as opposed to a mere condition. Eating dinosaur eggs instead of other things is an action by a voluntary biological party ${ }^{17}$ and is in close proximity to the decline of dinosaurs. Hart and Honoré still have the task of investigating empirically to determine whether the factor contributed to dinosaur extinction, that is, whether mammals actually did eat dinosaur eggs. But once the causal decision maker clears that hurdle, no real questions remain.

Professor Dray finds that Hart and Honoré's distinction between causes and mere conditions is problematic. He argues that the perspective of the party is important in defining what is voluntary and abnormal. For example, the victim of a sub-Saharan drought may view her inability to get food as a product of the weather, but international authorities may view it as a product of the local government's negligence in not foreseeing the effects of cyclical drought conditions and not storing food in anticipation of this foreseeable event. ${ }^{18}$ In each instance, the facts and circumstances considered in need of explanation by the party analyzing the malady affects the determination of what caused the malady.

17. One may object to the characterization of animals as having "free wills," or at least to the notion that animals are capable of voluntary action. Within the context of this example, however, it seems reasonable to attribute voluntary notions to both dinosaurs and mammals.

18. Dray, supra note 3 , at 17 . 
The problem of perspective can be generalized because all causal decision makers are limited by the nature and kind of facts with which they are presented. In trying to achieve the goal to which the causal inquiry is directed (preventing future drought, for instance, or assigning responsibility for the present drought), the causal decision maker is limited by the facts and circumstances that affect his perspective. He can alter his perspective to some extent by augmenting the available information, but cannot alter the limitations of his causal position. Accordingly, judges, like historians, biologists, and economists are influenced by their own perspectives. These causal decision makers can only determine causal responsibility in the context within which the legal, historical, economic, or biological facts exist. The determination of causal responsibility changes with the causal decision maker because each decision maker has a different perspective. Consequently, there is an indeterminacy in causal responsibility. It is not surprising that as judges have become less important in determining responsibility in traditional common law areas, approaches to causal responsibility have changed. In addition, as legislatures and administrative agencies have become more important in defining social responsibility the focus of debate has shifted to different concerns. ${ }^{19}$

The dinosaur example poses similar problems of perspective. In order to view climatic changes as causes, a causal decision maker must have a particular causal perspective. A climatic circumstance that is abnormal when viewed within a ten-year frame may be normal when viewed from the perspective of centuries or longer. From the perspective of an era, the presence of a comet or meteor or an unusual run of weather are normal and expected events. Therefore, causal responsibility cannot be assigned to them. For Hart and Honoré, determining a normal time period depends on the type of causal inquiry. If the inquiry is an explanatory one, the normal time period is that in which the explanatory inquirer is looking for causal answers. If the inquiry is an attributive one, the time period is that in which the causal inquirer is able to apply the causal goals of his inquiry. These time periods may or may not be the same, but they demonstrate the extent to which attributive and explanatory questions may overlap in the causal inquiry.

In order to understand the importance of causal goals and causal decision makers, it is important to examine their implication for Hart and Honoré's notions of attributive and explanatory causes. Once the causal decision maker is assigned, the scope of the explanatory inquiry is determined. The parameters of the inquiry are also set when the questions for decision are defined. For example, in a tort case the questions put to a common law judge are different in magnitude from the issues placed before an administrative agency. The kind and amount of data a court may collect to answer questions are more restricted than an administrative agency may collect. Furthermore,

19. See G. Calabresi, a Common law in An Age of Statutes 44-79, 163-66 (1982), 
courts are limited by the facts of the case before them, whereas administrative agencies are free to weigh broader policy considerations.

When a judge attempts to determine whether a water company or an aggrieved homeowner ought to bear the consequences of an unprecedented frost, he cannot measure the prospective consequences of his decision. ${ }^{20}$ The judge cannot know in advance whether placing the burden of the damage on the water company will force it out of business, or if the price of water will increase so much that some consumers will need to reduce their consumption. Similarly, the judge cannot know whether placing liability on the homeowner will, in the long run, lead homeowners to organize neighborhood watches to prevent damage to their water hydrants during unprecedented frosts. In contrast, an administrative agency can determine the best means of solving the problem by undertaking empirical research and implementing temporary rules. Thus, the scope of the explanatory inquiry increases as the causal decision maker moves from the courts to administrative agencies. Similarly, the scope of explanatory inquiry increases where judges, not juries, decide issues because the juries are more limited in their ability to examine causal questions than are judges. $^{21}$ This analysis demonstrates that the scope of decision making is defined by the chosen causal decision maker.

Similarly, when the decision maker chooses a causal goal he also determines the attributive inquiry. For example, a historian will view the question of who caused the Mexican-American War of 1846 differently if his goal is to enable nations to retain a certain amount of national pride than if he regards national pride as outside the permissible goals of historical analysis. ${ }^{22}$

20. See Blyth v. Birmingham Waterworks Co., 11 Ex. 781,156 Eng. Rep. 1047 (1856) (holding that the waterworks company was not liable for the consequences of an unprecedented and unforeseeable frost); see also infra text accompanying note 27.

21. This can be seen in the way in which the Restatement (Second) of Torts treats the role of the judge and jury in deciding issues of negligence. Compare Restatement (SECOND) of Torts $§ 328 \mathrm{C}$ (1965) with id. \& 328B.

\section{\& 328B. Functions of Court}

In an action for negligence the court determines

(a) whether the evidence as to the facts makes an issue upon which the jury may reasonably find the existence or non-existence of such facts;

(b) whether such facts give rise to any legal duty on the part of the defendant;

(c) the standard of conduct required of the defendant by his legal duty;

(d) whether the defendant has conformed to that standard, in any case in which the jury may not reasonably come to a different conclusion;

(e) the applicability of any rules of law determining whether the defendant's conduct is a legal cause of harm to the plaintiff; and

(f) whether the harm claimed to be suffered by the plaintiff is legally compensable.

$\S 328 C$. Functions of Jury

In an Action for negligence the jury determines, in any case in which different conclusions may be reached on the issue:

(a) the facts,

(b) whether the defendant has conformed to the standard of conduct required by the law,

(c) whether the defendant's conduct is a legal cause of the harm to the plaintiff, and

(d) the amount of compensation for legally compensable harm.

22. Dray suggests that Graebner's discussion of the causes of the Mexican-American War of 1846 could be viewed quite differently. Dray, supra note 3 , at 19 . Graebner argues that the United States was responsible for the war because when there is a conflict between a strong power and a weaker one, unless the weaker capitulates, the stronger power insists on war. Graebner concedes 
It is not possible for causal decision makers to determine questions of attributive causation independently of their causal goals. Attributive causation and causal goals are opposite sides of the same question. Once the historian as a causal decision maker chooses the goal, he has locked himself into a decision.

The application of Hart and Honoré's notions of causation to the problem of the extinction of dinosaurs also illustrates how choosing a goal influences the decision maker's conclusions. The climatologist's explanatory inquiry is different from the explanatory inquiry of the paleontologist. In order for a paleontologist to consider climatic factors as explanatory causes or conditions, a climatologist must determine whether those factors are within the causal inquiry. Even if climatic factors are brought within the inquiry, however, the paleontologist and the climatologist may view the attributive question of what constitutes a cause or condition differently. Similarly, the causal decision maker's determination as to what constitutes an attributive cause will change with the nature of the causal goals. In the case of the extinction of the dinosaurs, causal decision makers get different answers depending on whether they ask how alteration of the status quo led to the dinosaurs' extinction, or whether they ask what causal factors could have been altered to allow the dinosaur to survive. Adopting the first causal goal leads the decision maker to conclude that the attributive causes were the climatic or other changes that altered the status quo. The second causal goal permits the decision maker to include in the attributive causes the possibility that the dinosaurs' genes or their actions contributed to their extinction. By defining the causal goal, the causal decision maker limits the range of attributive causes of the dinosaurs' extinction.

\section{ECONOMists AND Causation}

Hart and Honoré believe that the distinction between causes and conditions centers primarily on retrospective considerations, that is, how current causal issues will influence settled questions. Abnormality, voluntariness, and temporal connection ${ }^{23}$ are all retrospective considerations of what produced given results. Modern law and economics theorists ${ }^{24}$ view

that the Mexican government engaged in provocative actions, but contends that the Mexican government had the right to insist as a matter of pride that it would not capitulate. Dray suggests that this argument demonstrates the difficulty of the use of causal goals. Graebner uses a value system to establish both the conditions (for example, the actions of the Mexican government), and causes (for example, the several alternatives available to the United States government) of the war.

23. H.L.A. Hart \& A. Honoré, supra note 2, at 26-61.

24. The modern law and economics movement owes a great deal to the intellectual efforts of various "noneconomic" thinkers. In particular, much of the "law and economics" literature is a product of concerns that were voiced by the legal realists, and at least some can be traced back indirectly to Holmes and other precursors to the legal realist movement. See, e.g., G. GiLmore, The Ages of AMERICAN LAw 99-106 (1977) (realists understood and used social science in an attempt to explain the law as a search for a single correct theory of law); H. Pohlman, Justice Oliver Wendell 
the issues quite differently. ${ }^{25}$ The key issues for them are prospective, that is, they are concerned with the implications of their view of causation on future situations.

One might argue that economists have provided the courts with a definition of causation by defining wealth maximization or social welfare maximization as the appropriate causal goal. Although economists understand that there is an inherent conflict between corrective justice and social welfare, they choose social welfare maximization as a goal. Economists use the term "cause" to explain those factors that contribute in any way to economic efficiency, wealth, or social welfare. The definition of cause is not appropriate, however, for two reasons. First, there are not clear, available wealth-maximizing or efficiency-producing solutions available for judicial or other decision makers. The economic theory of the "second best" 26 suggests that it is impossible on the basis of theory to decide unambiguously what will in fact contribute to wealth maximization or social welfare. Accordingly, economic efficiency, social welfare, and wealth maximization are likely to remain undefined in judicial decision making. Second, even if courts specify completely the conditions of social welfare maximization, those determinations do not thereby produce a definition of causation. The reason is that economists' allocation of liability is separated from the causal question.

The water damage case discussed above ${ }^{27}$ illustrates that the goals of social welfare or wealth maximization do not by themselves inform the court how to determine causation. These goals do not help the court choose between a negligence standard, which would require the innocent landowner

Holmes \& Utilitarian Jurisprudence 164-65 (1984) (legal realists owe much to Holmes's universal theory of liability).

The rationale for talking about the law and economics theorists in connection with an analysis of causation is that commentaries use the "language" of the law and economics movement. As a defense to the charge that this analysis is ahistorical, I would point out that most current legal thinking is not analyzed in terms of Holmes' and Frank's theories. See O. Holmes, The Common Law (1881); J. Frank, Courts on Trial (1949). Courts and commentators now reference Calabresi's and Posner's theories. See G. Calabresi, The Cost of Accidents (1970); R. Posner, Economic Analysis of LAW (1977).

25. In their preface to the second edition of Causation in the Law, Hart and Honore discuss the differences between their views and the views of several prominent law and economics theorists. H.L.A. HART \& A. Honoré, supra note 2, at lxviii-lxxvii (arguing that the economists are causal minimalists); see supra text accompanying note 5 .

26. The theory of the second best states that "it is not true that a situation in which more, but not all, of the optimum conditions are fulfilled is necessarily, or is even likely to be, superior to a situation in which fewer are fulfilled." Lipsey \& Lancaster, The General Theory of Second Best, 24 REv. ECon. STud. 11, 12 (1956). In general, the theory states that social welfare will not be increased automatically by using the results of an economic analysis that is geared toward realizing optimum conditions. When all of the assumed optimum conditions are not met in reality, it is possible that efforts to meet one of the optimum conditions will worsen social welfare. In short, social welfare is not maximized by merely maximizing the number of optimal conditions which are met. For a discussion of this theory from a legal perspective see Henderson, Extending the Boundaries of Strict Products Liability: Implications of the Theory of the Second Best, 128 U. PA. L. Rev. 1036 (1980); Markovits, A Basic Structure for Microeconomic Policy in Our Worse-Than-Second-Best World: A Proposal and Related Critique of the Chicago Approach to the Study of Law and Economics, 1975 WISC. L. REv. 950.

27. Blyth v. Birmingham Waterworks Co., 11 Ex. 781, 156 Eng. Rep. 1047 (1856); see supra text accompanying note 20 . 
to bear the cost of the water damage, and a strict liability standard, which would require the water company and, ultimately, its customers to bear the cost. Since the economists have drained causation of its meaning, they are not able to say whether either standard appropriately places liability on the causally responsible party. The indeterminacy stems not from the particular example, but utilization of a goal that fails to take account of important values other than economics or social welfare maximization. Traditional legal causation analysis evaluates the individual outcomes relative to the particular participants in a proceeding. In contrast, social welfare maximization eliminates the comparison of individuals because it is potentially inconsistent with the independent goal of social welfare maximization to worry about individual outcomes.

Both the early and later economists start with the same instrumental goal of economic efficiency, but they define causation differently. The difference between the early economists, Coase and Calabresi, and the later economists, Landes, Posner, Shavell, and Polinsky, however, is that Coase and Calabresi would argue that causation does not exist apart from the economic goals chosen. They do not deny that causation may exist for moral or other purposes, but they would question whether the traditional notion of causation can be used to achieve social welfare through the attribution of liability in a legal setting. The early economic theorists view the the causal inquiry as purely explanatory and attributively irrelevant. For example, the factors that contributed to the water damage in the above illustration are definable, but the explanation is irrelevant for attributive purposes. The later economic theorists, however, make a different argument that causation does exist and that it is possible to define causation in economic terms.

The later economic theorists would argue that either the water works company or the homeowner caused the accident by taking insufficient precautions. Liability should be assigned based purely on whether one or the other party contributed to the accident in a wealth-maximizing or economic efficiency sense. The homeowner and the water works company both contributed to the accident, and liability is attributable to them based upon their contribution to economic efficiency or wealth. Thus, causation has been reduced to wealth maximization or economic efficiency. This notion of attributive causation is so broad, however, that it destroys causation as an effective means of discrimination. This economic perspective does not permit the causal inquirer to distinguish causal from contributing factors.

Economists may help to define negligence standards by demonstrating their impact on economic goals. The Learned Hand formula, which balances the cost of precautions against the likelihood and gravity of harm, has helped some courts to determine negligence. ${ }^{28}$ The formula, however, does not produce a definition of causation that distinguishes between causal factors.

28. United States v. Carroll Towing Co., 159 F.2d 169, 173 (2d Cir. 1947). Judge Learned Hand proposed a formula for determining negligence that balanced the burden of adequate precautions (B) with the product of the probability of harm (P) and the gravity of harm (L). If B $>P L$, the party 
The only question that a court applying Hand's formula must decide is whose actions - the alleged tortfeasor's or the victim's-contributed to a diminution in social welfare. The calculation of economic costs may require the court to conclude that the actions of the alleged tortfeasor are a cause even if, for example, the relationship between the alleged tortfeasor and victim is very attenuated. The conclusion that the alleged tortfeasor has been negligent lacks the notion of wrongfulness if it is based only on the cost of avoiding the accident. The economists' approach thus removes moral issues from the causal inquiry.

Consideration of four economists' views on causation illustrates the lack of moral perspective in the economists' approach. Coase, for example, views the causal inquiry as primarily explanatory. ${ }^{29}$ Coase would inquire about the causes of an event to determine how the event in question occurred. The attributive causal inquiry, however, does not exist for him. In addition, Coase is unable to distinguish between cause and conditions. Just as the attributive question is outside the causal inquiry, the question whether an event is a cause or a condition does not exist. Rather, Coase has collapsed the causal inquiry into a single question about explanatory conditions. The assignment of causal goals and decision makers is irrelevant because any causal choices made are subject to the intervention of individual responses and the market. Consider, for example, the common law judge who assigns liability in the water damage case to the water works company. In that case, either the judge's decision will be thwarted by the response of individuals to the decision, or it will become irrelevant to the outcome because it will simply produce the same result as would have been produced by market forces and individual responses.

Individual responses thwart the assignment of liability by adjusting market values so as to render the assignment of liability irrelevant. For example, assume that there is a rule that imposes liability on ranchers for their roaming cattle. The ranchers may nevertheless find it economically attractive to sell out to farmers whose crops are damaged by the cattle instead of risking liability. The market's measurement of the relative value of their competing interests will determine if the rancher and the farmer will peacefully coexist or if one will buy out the other. Since the assignment of liability does not influence the market's measurement of value, it will not influence the end position of farmers and ranchers. If the market cannot work effectively, however, then the assignment of liability to the rancher matters. Regardless of the fact that an assignment to the wrong party will affect economic efficiency, assigning liability does not matter because the result will be compared to the result that would have been achieved in the market through individual action.

who did not take the adequate precautions would be held accountable for the injury. See also American Hosp. Supply Corp. v. Hospital Prod. Ltd., 780 F.2d 589, 608-09 (7th Cir. 1986) (Swygert, dissenting).

29. See Coase, The Problem of Social Cost, 3 J. L. \& Econ. 1 (1960); see also H.L.A. HART \& A. HoNORÉ, supra note 2 , at lxx-lxxi. 
Applying this analysis to the dinosaur example illustrates that, for Coase, all of the potential causal explanations are simply conditions. Since all of the five factors identified as possible causes ${ }^{\mathbf{3 0}}$ are potentially mutable each factor is also potentially fully responsible. The biologist's or the judge's choice of which factor caused the dinosaur's extinction may be irrelevant to the outcome since individual action will lead to the same outcome irrespective of the allocation of liability. Alternatively, the causal decision maker has the difficult task of attempting to replicate the result that would have been achieved if markets worked appropriately. Accordingly, the question in the dinosaur example is simply an instrumental one: Will the market results be altered by the assignment of causal responsibility? If the answer is no, then from the Coasian perspective all of the potential factors are simply conditions and there is no cause. If the answer is yes, then any or all of the factors could be responsible. Cause in an attributive sense, then, does not exist.

Calabresi has developed an analogous view of the law. ${ }^{31}$ Calabresi says that in order to attribute causation to a particular factor, the causal decision maker must engage in a complicated calculus to create a hierarchy of causal factors. ${ }^{32}$ In determining how to allocate causation among the five factors in the dinosaur example, the causal decision maker would choose the factor (or factors) that, if altered, would have imposed the lowest social cost on society. Although there are competing goals like equity and loss spreading, they conflict with the goal of minimizing cost and, therefore, are irrelevant. ${ }^{33}$ Liability is determined not by causal relationship, but by the complicated calculation of whose actions cost society the most. In making this calculation the causal decision maker does not address the attributive question at all. To the extent that cause enters into the least cost-avoider analysis, it is as a means of explaining the causal relationship. Thus, under Calabresi's analysis, all five of the factors which could have been causes are explanatory conditions.

Unlike Coase, Calabresi is not certain that the market is always the best measure of the social calculus. He would rely instead on legislatures and, to a lesser extent, on the courts to attribute liability. For both Calabresi and Coase, however, the causal inquiry is separate from the attributive question. The causal inquiry is simply an explanatory process; attribution is left to more powerful forces.

Landes and Posner view the question of how to allocate liability differently. ${ }^{34}$ For them, all five factors are attributive causes. The task for the decision maker determining causation is to decide which causes, among all the

30. See supra text accompanying notes 8-12.

31. Calabresi, Some Thoughts on Risk Distribution and the Law of Torts, 70 Yale L.J. 499 (1961). For Hart and Honoré's comments on Calabresi, see H.L.A. Hart \& A. Honoré, supra note 2, at lxxilxxiii.

32. Calabresi, Concerning Cause and the Law of Torts: An Essay for Harry Kalven, Jr., 43 U. CHI. L. Rev. 69, at 73-91 (1975). For a thoughtful discussion of Calabresi, see Wright, Actual Causation v. Probabilistic Linkage: The Bane of Economic Analysis, 14 J. Legal. STUd. 435 (1985).

33. Calabresi, supra note 32.

34. Landes \& Posner, supra note 4, at 109. For a response to Posner, see H.L.A. HART \& A. HonORÉ, supra note 2, at xviii. 
potential causes, should bear liability, when the instrumental goal is wealth maximization. Landes and Posner would allocate liability based on how much these causal factors contributed to the loss of societal wealth. ${ }^{35}$ The rule for assigning liability takes from those who contributed to the diminution of societal welfare and gives to those who were damaged. The market determines this allocation. In the dinosaur example, genes could be the cause of the dinosaurs' failure to confront the potential vagaries of climate successfully. Not only could the dinosaur have caused its injury, but it has contributed at some level to the injury. The causal inquiry is attributive, and seeks to determine the party that in a wealth maximizing sense, should be held liable for the injuries. Since the goal of the causal decision maker is clear and not in conflict with other concerns, it is possible to define exactly the responsible parties and the level of their liability.

Shavell and Polinsky have extended a similar model of economic analysis to issues of participation ${ }^{36}$ and risk aversion ${ }^{37}$ (issues not directly recognized by either Calabresi or Coase). Shavell's and Polinsky's views are similar to those of Landes and Posner with one main exception: they replace the goal of wealth maximization with economic efficiency. ${ }^{38}$ The causal decision maker's task is to determine how to allocate liability among all of the causes that produced the results in order to achieve economic efficiency. Since Polinsky and Shavell have adopted economic efficiency as the goal of the causal inquiry, causation exists only in an attributive sense. All contributing factors are attributive causes. The weight of attribution is determined by empirical facts. In examining the dinosaur problem, they would ask how to apportion liability among the responsible causes in order to achieve economic efficiency. Dinosaurs might be charged with responsibility because they could have developed selfish genes that would have adapted to future climatic changes or could have altered their body sizes to reduce their participation in the risk-

35. Landes \& Posner, supra note 4, at 110-11.

36. Shavell, Strict Liability Versus Negligence, 9 J. Legal Stud. 1 (1980).

37. Polinsky \& Shavell, The Optimal Tradeoff Between the Probability and Magnitude of Fines, 69 AM. Econ. Rev. 880 (1979); Shavell, An Analysis of Causation and the Scope of Liability in the Law of Torts, $9 \mathrm{~J}$. Legal Stud. 463 (1980). The Shavell and Polinsky model is explained in greater detail and with examples in A. Polinsky, An Introduction to Law and Economics (1983).

38. The difference between wealth maximization and economic efficiency has been the subject of much debate among economists and lawyer economists. Economic efficiency implies that one is pareto efficient-it is not posssible to make any individual better off without making someone else worse off. This requirement, while superficially attractive, is extremely difficult to apply in policy situations. It is this policy implementation problem which has led people like Posner to adopt wealth maximization as a goal. Wealth maximization requires that whatever change is instituted increases the net wealth of society. Wealth maximization violates pareto principles of economic efficiency in two very important ways. First, a rule of wealth maximization does not require that everyone be made better off by a change in a liability rule. Second, a wealth maximization rule measures the change of value in terms of wealth. Since wealth is dependent on initial distributions of resources and individual choices, wealth maximization is not equivalent to society maximizing individual utility in the pareto-efficient sense.

For a defense of wealth maximization as a value see Posner, The Economics of Justice 60-119 (1981); Johnsen, Wealth is Value, $15 \mathrm{~J}$. Legal Stud. 263 (1986). But see Dworkin, Why Efficiency? 8 Hofstra L. Rev. 563 (1980) (wealth is an unappealing ethical basis for legal decisions); Kronman, Wealth Maximization as a Normative Principle, 9 J. Legal Stud. 227 (1980). 
creating activity. Similarly, mammals might be charged with the responsibility for the dinosaurs' extinction if their actions contributed in any way to that extinction. By eating dinosaur eggs, for example, mammals may have reduced the genetic diversity of the dinosaur population.

How economists view causal questions demonstrates the importance of defining the causal goal and the causal decision maker. The views of Hart and Honoré and the four economists discussed above in terms of the dinosaur problem are outlined in Table 1. The last three columns show what each of these theorists believes ought to be the causal goal, who ought to be the causal decision maker, and whether the inquiry is attributive or explanatory. Each of the economists views the causal goal as substantially a product of the market.

For Coase, Landes, and Posner, the Chicago contingent, the market alone defines the causal goal of the tort system. ${ }^{39}$ Calabresi, Shavell, and Polinsky theoretically permit other concerns to enter into the equation, but for each of them, the market is ultimately the only appropriate measuring instrument. Calabresi argues that the determination of causal goals should be left to legislatures or administrative agencies because they are in a better position than are the courts to determine the market result. ${ }^{40}$ Shavell and Polinsky recognize that it would be difficult for courts to determine the result the market would have produced, and therefore argue that the appropriate results depend critically on the empirical facts in the system. ${ }^{41}$

Each of the economists connects his causal goal to a causal decision maker who is in the best position to achieve that goal. The problem with the economists' perspective can be seen in the way each of these theorists approaches Hart and Honoré's distinction between cause and condition.

Calabresi and Coase would view each of the five factors in the dinosaur example as mere conditions, not causes. These factors are part of the background information from which the causal decision maker can decide how to replicate the market. In order to view the factors as mere conditions, however, the causal decision maker must disconnect the causal inquiry from the assignment of liability. As a consequence, causation in the attributive sense does not exist. A factor may contribute to an event but not be part of the attributive process. As long as the attributive process is able to achieve its causal goal, the causal connection is irrelevant.

Landes, Posner, Shavell, and Polinsky would view each of the five factors as an attributive cause because each factor contributed to the extinction of the dinosaur. The causal decision maker must decide how to allocate liability among the attributive causes. According to these theorists, liability should be allocated according to how each factor contributed to (or detracted from)

39. Landes \& Posner, supra note 4 , at 110.

40. See Calabresi, supra note 32, at 84-100. Calabresi notes that there are multiple goals for the tort system, but he has difficulty working those goals into causal language. These other goals ultimately are decided after cause is defined. Calabresi, supra note 32, at 105-08.

41. See, e.g., A. Polinsky, supra note 37, at 123-26. 


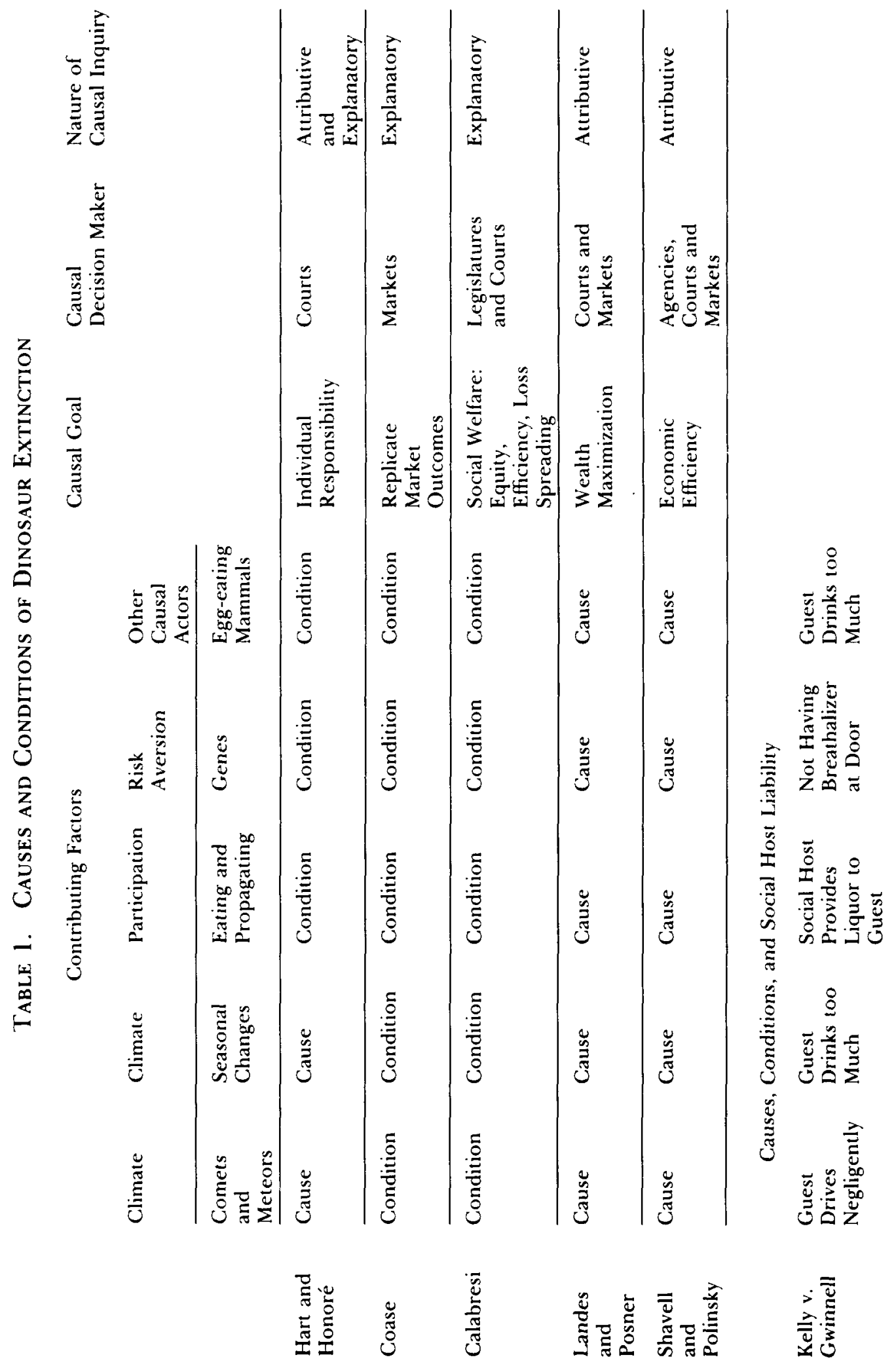


wealth maximization or social welfare. Explanatory and attributive conditions are indistinguishable because, at least within the realm of choices available to causal decision makers, all factors are causes. The inquiry for these economists is purely attributive, confined to determining what factors effect changes in wealth or economic efficiency.

Table 1 illustrates weakness of the economists' view of causation. The economists have collapsed causation into either explanatory conditions or attributive causes. The causal decision maker is left with little means by which to distinguish conditions from causes. Although Calabresi and Polinsky explicitly discuss including other values in causal decision making, ${ }^{42}$ each ultimately ignores the kinds of questions that Hart and Honore raise with respect to causes and conditions. The reason for the omission is clear. The economists are primarily focusing on prospective concerns. These concerns do not allow for considerations of individual justice. According to Landes and Posner, "causation becomes a result rather than a premise of the economic analysis of accidents." 43 If the courts should include considerations of individual equity in their decision making, however, they need to distinguish between causes and conditions. Of the theorists discussed in this comment, only Hart and Honoré make that distinction. ${ }^{44}$

The economists' perspective can increase the number of issues that causal decision makers examine. For example, the argument that a potential tortfeasor or victim can produce injury by increasing his or her participation in an activity is less likely to arise in Hart and Honoré's scheme than in the economists' scheme. Because economists focus on the impact court decisions have on social welfare, they ignore the actions of individuals. In contrast, Hart and Honoré's concerns focus on the actions of individuals. Even when not discussing moral actors, however, Hart and Honoré can meaningfully

42. G. Calabresi, The Costs of Accidents 24-35 (student ed. 1970); A. Polinsky, supra note 37 , at $7-10$.

43. Landes \& Posner, supra note 4 , at 110.

44. The courts' equitable assignment of liability in other areas of the law is similarly dependent on the distinction between causes and conditions. See, e.g., Fletcher, The Right and the Reasonable, 98 Harv. L. Rev. 949 (1985). George Fletcher argues that legal systems that focus on reasonableness fail to draw a crucial distinction between wrongfulness and responsibility, and that this problem also exists in American criminal law. He concludes that American law is concerned with the notion of reasonableness, whereas the law in other countries distinguishes between wrongfulness and responsibility, that is, between justification and excuse. Fletcher notes that the flat notion of reasonableness prevalent in American law cannot distinguish meaningfully between various kinds of defenses to criminal activity. He divides these defenses into those that are primarily concerned with wrongfulness (the absence of justification) and with responsibility (the absence of excuse).

If Fletcher's notions are applied to the concept of causes and conditions, it is clear that conditions are events or actions that are responsible but not wrongful. Normal things are not causes of actions because they are part of the background. Similarly, actions that are not voluntary are not wrongful, even when they are responsible actions (for example, when they are causally connected). In contrast to conditions, causes are those actions that are both wrongful and responsible. Just as Fletcher finds much of American law to be flat and incapable of producing the distinctions that notions of wrongfulness and responsibility dictate, I find that the economic analysis of tort liability is similarly flat and incapable of distinguishing between those actions that are wrongful but are responsible. Economists who write about tort law have collapsed the concerns of tort law into a one-dimensional analysis that is ultimately not helpful to courts. 
distinguish between causes and conditions. For example, Hart and Honoré, could argue that the dinosaurs' eating and procreating habits are not causes because they are involuntary. The question whether the actions are causes is meaningful to them.

A decision maker following Hart and Honoré's model is unlikely to ask whether certain actions are causes even in situations where the participation of the tortfeasor or the victim is important. Take the example of the automobile driver who drives carefully (nonnegligently) but frequently. The chance that such a driver might in fact hurt an innocent pedestrian might be the same as for the driver who drives negligently but infrequently. 45 This second order problem is ignored in most tort law or, at least, in negligence situations. The causal decision maker following Hart and Honoré simply would not view the tortfeasor's or the victim's frequency of participation in the activity as an issue. The traditional common law justification for not taking the participation factor into account is that tort law need not resolve all of society's problems and that regulation through insurance rates and other procedures can solve some of the problems. ${ }^{46}$ The objective of the traditional tort system is justice, not social welfare. From the perspective of maximizing

45. For a further discussion of this problem see, A. Polinsky, supra note 37, at 38-49. This discussion draws much of its inspiration from Shavell, supra note 36.

46. Indeed, in some areas tort law has attempted to induce the potential tortfeasor to take account of such liability, most notably by making product manufacturers strictly liable for the injuries caused by their products. Restatement (Second) of Torts $\$ 401$ A (1977). To the extent that product manufacturers are strictly liable, they will take account of some of these participation issues. Thus, this tort law rule reflects concerns that are also of central importance to the economist. While these concerns certainly predate the recent contributions of economists to the literature on tort law, it is increasingly clear that these concerns contributed to the modern law and economics movement. See R. Epstein, Modern Products Liability Law 26-30 (1980).

The development of strict product liability is therefore a useful focus for tracing the growing importance of economic analysis in the law of torts. In the Restatement of Torts, absolute liability was imposed only in cases involving livestock and operators of ultrahazardous activities. RESTATEMENT OF TorTs $\S \S 504-24$ (1938). Accidents involving products used by consumers or business were covered by negligence standards. Id. $\$ \S 308-408$. No provision was made for strict product liability, and negligence was discussed in noneconomic terms. See, e.g., id. at $\$ 391$, comment a (liability "may often be avoided by giving . . . the information necessary to enable it to be safely used, or to afford those who are to use it an opportunity to decide whether to do so or not"). This is the traditional reasonable man standard which does not account for the economic cost of safety devices, warnings, or the results of not using the device or heeding the warnings. In contrast, the Restatement (Second) of Torts states that "[o]ne who sells any product in a defective condition unreasonably dangerous to the user or consumer or to his property is subject to liability for physical harm thereby caused to the ultimate user or consumer, or to his property . . . " REstatement (SEcond) of Torts § 402(A)(1) (1965). The purpose of the rule is to hold the seller liable for the use of his products, even though he has used all possible care in the preparation and sale of the products. Id. comments a, $\mathrm{f}$. Section 402(A) was designed to meet the inadequacy of contractual remedies such as breach of warranty, and as such it was based on an efficiency argument that the business person was best able to care for both the product and potential harm caused by the product. Section $402(\mathrm{~A})$ is applicable to the business person rather than the individual involved in an occasional sale not only because the business person has a "special responsibility" to the public, but also because business can more efficiently pay the costs incurred (by insuring and passing on costs of accidents to consumers in the form of higher prices). To the extent that $\S 402(\mathrm{~A})$ relies on the efficiency argument, the section is attentive to the participation issues that are at the heart of the economists' analysis. See Page, Generic Product Risks: The Case Against Comment $k$ and for Strict Tort Liability, 58 N.Y.U. L. Rev. 853 (1983). 
society's welfare, however, the grandmother who carefully but frequently drives her automobile up and down the street is a social concern.

Hart and Honoré as well as the common law courts are concerned with retrospective considerations of responsibility. Retrospective concerns are vindicated by looking for the causal agent in Hart and Honoré's traditional sense. Hart and Honoré define the causal agent as the nearest voluntary, responsible party. ${ }^{47}$ At common law an injured plaintiff could not sue a defendant if a voluntary action by an independent agent intervened between the action of the potential defendant and the injury of the plaintiff. For example, a landlord was not responsible for injuries to a tenant where a thirdparty criminal intervened. ${ }^{48}$ Similarly, a police officer injured in a collision with a stolen automobile could not sue the owner for negligence even though the owner had left the keys in the ignition in a high crime area. ${ }^{49}$ In both cases, the voluntary action of an independent third party intervened. To the common law court, the actions of the landlord and the car owner are merely conditions and not causes.

This notion of the nearest voluntary responsible party as a cause can be applied to determine whether mammals caused the extinction of dinosaurs. To Hart and Honoré, the proximity to the dinosaurs' extinction of the mammals' choosing to eat dinosaur eggs instead of something else would lead to the conclusion that the mammals caused their extinction. This view of causation, however, has not prevailed in modern decisions where causal relationships matter, as can be seen in tort liability areas as diverse as product $\operatorname{defects}^{50}$ and automobile accidents. ${ }^{51}$

\section{IV}

\section{Causation and the Social Host}

The common law courts' changing focus with respect to causation can be seen clearly in the extension of liability to social hosts who provide alcoholic beverages to individuals who subsequently injure third parties. The common law rule that the subsequent injury is too attenuated to lead to liability against the social host was first tempered by extending liability to adults who provided alcoholic beverages to minors. ${ }^{52}$ This extension to social hosts who

47. H.L.A. HaRT \& A. Honoré, supra note 2, at 60-72.

48. See Trentacost v. Brussel, 82 N.J. 214, 412 A.2d 436 (1980) (altering the common law rule to extend liability to landlords in some situations involving third party criminals). For a precursor to the modern extension, see Brauer v. New York Cent. \& H. R.R. Co., 91 N.J.L. 190, 103 A. 166 (1918) (because defendant railroad failed to protect plaintiff's freight, railroad is liable for the consequences of foreseeable criminal intervention by a third party).

49. See Hill v. Yaskin, 75 N.J. 139, 380 A.2d 1107 (1977) (suit against car owner remanded for development of facts on duty of car owner).

50. See Beshada v. Johns-Manville Products Corp. 90 N.J. 191, 447 A.2d 539 (1982) (product manufacturers are liable even if manufacturer did not know of possible harm).

51. See Kelly v. Gwinnell, 96 N.J. 538, 476 A.2d 1219 (1984); see also infra text accompanying notes 55-59.

52. Sutter v. Hutchings, $254 \mathrm{Ga}$. 194, 327 S.E.2d 716 (1985) (social host who provides alcoholic beverages to a minor may be liable to third party injured as a result); Linn v. Rand, 140 N.J. Super. 
serve minors was based on traditional notions of causation and responsibility. The reasoning underlying these decisions is that because a minor might not be aware of the consequences of driving while intoxicated, the adult social host who provided liquor to a minor knowing that the minor would soon be driving was the closest responsible individual. This reasoning is similar to the reasoning underlying statutory rules that make commercial vendors liable for injuries to third parties resulting from the behavior of obviously intoxicated customers served liquor by the vendors. ${ }^{53}$ The statutes are premised on the belief that one may reasonably conclude that an establishment serving obviously intoxicated customers causes the patron's later behavior. The reason is that a commercial establishment that provides liquor to an obviously drunk patron knows the danger that action holds for others, and the intoxicated patron may no longer be in a condition to accept voluntarily and responsibly the consequences of his actions. In addition, these statutory provisions often make the dram shop strictly liable for a particular set of consequences. ${ }^{54}$ In Hart and Honoré's terms the closest voluntary actor is the commercial vendor. The social host who provides liquor to an adult, on the other hand, has no special expertise and is likely to be no more aware of the potential ensuing dangers than the intoxicated guest. In terms of traditional notions of causation, there is no reason to hold the social host responsible. Accordingly, serving liquor to social guests is not abnormal, but serving liquor to intoxicated customers is. To the extent that they focused on the questions of causation and responsibility, the common law courts used Hart and Honoré's traditional concepts to determine liability.

A number of courts have moved beyond the traditional common law approach to adopt a model based upon a notion of causation similar to that advanced by the law and economics school. In Kelly $v$. Gwinnell, ${ }^{55}$ the New Jersey Supreme Court held that a social host who provides liquor to an adult social guest, knowing that the guest will thereafter be operating a motor vehicle, is liable to third parties injured as a result of his intoxicated use of the motor vehicle. The court rejected traditional causation. The court did not reason that the intoxicated guest lacked responsibility or that, at some level of intoxication, the host and not the driver could be held liable because the

212, 356 A.2d 15 (1976) (social host who provides alcoholic beverages to a minor, knowing the minor was about to drive a car on the public highways, may be liable to third parties injured as a result); Koback v. Crook, 123 Wis. 2d 259, 366 N.W.2d 857 (1985) (social host who provides alcoholic beverages to minors is liable to third parties for injuries caused as a result of that action). But see Holmquist v. Miller, 367 N.W.2d 468 (Minn. 1985) (statute does not permit extension of liability to social host who provides alcoholic beverages to minors).

53. Rappaport v. Nichols, 31 N.J. 188, 156 A.2d 1 (1959); Sharp, Dram Shop Laus and Problems, 28 Ala. Law. 409 (1967); Note, Extension of the Dram Shop Act: New Found Liability of the Social Host, 49 N.D.L. REv. 67 (1972).

54. Sharp, supra note 53 , at $410-11$.

55. 96 N.J. 538, 476 A.2d 1219 (1984). But see McGuiggan v. New England Tel. \& Tel. Co., 398 Mass. 152, 159-62, 496 N.E.2d 141, 145-46 (1986) (holding that liability of social hosts should be determined by common law principles). 
intoxicated guest, like a minor, could not be responsible. ${ }^{56}$ Instead, the court focused on the social costs of drunk driving, stating: "When the court determines that a duty exists and liability will be extended, it draws judicial lines based on fairness and policy. In a society where thousands of deaths are caused each year by drunken drivers . . . the imposition of such a duty by the judiciary. . . . is both consistent with and supportive of a social goal-the reduction of drunken driving . . ."57 Thus, the causal question folded into larger tort law concerns of deterrence and risk spreading. ${ }^{58}$ When the court adopted the perspective of the law and economics school of social policy, it abandoned Hart and Honoré's notion of causation.

Adopting the law and economics perspective, however, does not necessarily imply complete rejection of Hart and Honorés distinction between causes and conditions. When courts use social policy in judicial decision making, they must distinguish between those factors to which responsibility should be attached, and those that contribute in some way but should be ignored. Tort law has altered the focus of concerns. Under Hart and Honoré's model, the court, as causal decision maker, would focus on the questions of voluntariness, proximity, and abnormality. The purpose of these tests is to impose liability for the costs of the injury on the individual who has caused it. Policy goals are, secondarily, products of these rules. For common law courts following the law and economics approach, individual justice is a secondary consequence resulting from the maximization of social welfare.

The Kelly case also illustrates the importance of defining social goals and the causal decision maker. When the Kelly court shifted its goal from the traditional common law concern of individual responsibility to the maximization of social welfare, what constituted a cause and a condition changed. The court now views the actions of social hosts, which it had traditionally seen as mere conditions, as causes. If the causal goal is social welfare maximization as that term is defined by the majority in Kelly and law and economics writers, then the court must maximize welfare. The dissent in Kelly argues against imposing a common law rule on social hosts. He argues that, due to its perspective, the court is not the proper body to make this determination. ${ }^{59}$ Rather, the legislature is in a better position to appreciate the social costs of drunk driving and devise the appropriate rule. ${ }^{60}$ The

56. For an example of a New Jersey court that did make this argument, see Figuly v. Knoll, 185 N.J. Super. 477, 449 A.2d 564 (1982) (bartender who serves drinks to known alcoholics may be liable for injuries to third parties).

57. Kelly v. Gwinnell, 96 N.J. 538, 544-45, 476 A.2d 1219, 1222 (1984).

58. "[W]e believe that the added assurance of just compensation to the victims of drunken driving as well as the added deterrent effect of the rule on such driving outweigh the importance of" the camaradie that is experienced at social gatherings where alcohol is served. Id. at $548,476 \mathrm{~A} .2 \mathrm{~d}$ at 1224.

59. Id. at 570, $476 \mathrm{~A} .2 \mathrm{~d}$ at 1235-36 (Garibaldi, J., dissenting).

60.

I do not propose to fashion a legislative solution. That is for the Legislature. I merely wish to point out that the Legislature has a variety of alternatives to this Court's imposition of unlimited liability on every New Jersey adult. Perhaps, after investigating all the options, the Legislature will determine that the most effective course is to impose the same civil liability on 
dissent, however, ignores the limitations inherent in the legislative process. The legislature may have access to more information enabling it better to engage in interest balancing, but that information is ordinarily irrelevant to the specific question that the common law court is required to answer.

The implications of Landes and Posner's causal perspective can be seen when applied to the social host problem. Landes and Posner believe that tort liability should be allocated among the contributing factors to the extent that these factors maximize wealth. ${ }^{61}$ The courts, then, must decide how best to help society to maximize wealth. Landes and Posner argue that most causation situations are special cases of the multiple tortfeasor problem. ${ }^{62}$ In trying to allocate liability in the social host situation, the courts must decide which party or parties could prevent an accident from happening at the least cost. ${ }^{63}$ If the social host is in a better position than the guest to appreciate the danger of futher liquor consumption by the guest, then the social host should bear the burden of preventing the injury to an innocent third person. Therefore, the common law ought to permit indemnification of the guest by the social host for any damages that are allocated to the host. If the guest can avoid the danger at a lower cost than can the social host, then she ought to bear the liability alone. In addition, if wealth maximization requires both parties to be careful, then each should bear some burden by permitting, for example, the social host to secure contribution from the guest or by holding the social host liable unless he has provided a breathalizer at the door.

Posner suggested in his early work that the courts' application of negligence rules was always efficient (by which Posner meant wealth maximizing). ${ }^{64} \mathrm{He}$ has now come to the conclusion that this early view was too narrow. ${ }^{65}$ Posner's original position is consistent with the reason for his change in position in my interpretation of Landes and Posner's theory. Posner originally thought that negligence was wealth maximizing because he thought one party or the other generally was in the better position to avoid

social hosts that the majority has imposed today. I would have no qualms about that legislative decision so long as it was reached after a thorough investigation of its impact on average citizens of New Jersey.

Id. at 570, 476 A.2d at 1235-36 (Garibaldi, J. dissenting); $f$. Miller v. Moran, 96 Ill. App. 3d 596, 421 N.E.2d 1046 (1981) (decision on further remedies is a legislative decision).

For a similar approach to the use of policy in judicial decision making, see Kelley v. R. G. Industries, $304 \mathrm{Md} .124,497$ A.2d 1143 (1985) (holding that a gun manufacturer cannot be held liable for injuries to innocent third parties under the traditional principles of tort law, but that policy permits the courts to hold the manufacturers of "saturday night specials" liable in (ort).

61. Landes \& Posner, Joint and Multiple Tortfeasors: An Economic Analysis, 9 J. Legal Stud. 517 (1980).

62. Id. at 529 (whenever it was possible to do so, common law courts adopted rules of contribution and indemnification that maximized wealth).

63. Id. at 533 .

64. Compare Posner, A Theory of Negligence, I J. Legal Stud. 29 (1970) (arguing that negligence is generally the efficient rule in tort cases) and Posner, Strict Liability: A Comment, 2 J. Legal Stud. 205 (1971) (strict liability is generally an inefficient system of assigning tort liability) with Landes and Posner, The Positive Economic Theory of Tort Law, 15 GA. L. REv. 851 (1982) (both strict liability and negligence can be wealth maximizing).

65. Landes \& Posner, The Positive Economic Theory of Tort Law, 15 GA. L. Rev. 851, $916-21$ (1980). 
accidents. In such a world, rules of negligence and contributory negligence would allocate accident costs to the party who, in terms of the Learned Hand formula, could best avoid accident costs and thus maximize wealth. Once Posner was convinced that this simple view of accidents was inaccurate, he had to accept the broader multiple tortfeasor perspective. ${ }^{66}$ Of course, both the revised Posner (with Landes) and the original Posner positions are consistent with viewing the causal inquiry in a purely attributive manner.

Landes and Posner would make the assumption in the social host problem that the cheapest way of avoiding an accident is to hold the guest liable for her actions. There are two reasons for making this assumption. First, the common law would allocate liability this way. Because the common law approach is wealth maximizing, making this assumption should result in wealth maximization. Second, by not holding social hosts liable for providing extra protection, courts put more responsibility on individuals and thus require less government intervention in the private lives of citizens. Despite this perspective, the causal inquiry remains an empirical one of allocating liability among all the parties and the choices they made affecting the way in which they interacted. For Posner and Landes, all of the potential causal agents are attributive causes.

By examining the economists' theories, Hart and Honoré's distinction between attributive and explanatory causes and between causes and conditions becomes clear. My analysis of their views demonstrates that the distinction between attributive and explanatory causes is difficult, but not meaningless. In moving from explanatory to attributive questions, the law and economics theorists have altered the focus of the debate. Coase and Calabresi are looking for noncausal answers to attributive questions and, consequently, they have had to develop an explanatory notion of cause. Posner and the later law and economics adherents have developed a purely attributive model of cause. Explanatory questions are not asked because the causal questions have no explanatory power outside the attributive framework. The fact that these shifts in focus leave no room for moral perspectives demonstrates the importance of the distinction between causes and conditions, and the importance of the interrelationship of the attributive and explanatory causal inquiries. It is only if the causal decision maker is capable of and does look at both explanatory and attributive questions that moral perspectives can be incorporated in the determination of causation, the assignment of responsibility, and the allocation of liability. Economists have drained the moral quality from the causal question by attempting to erase the distinction between attributive and explanatory causes. The result is an inability to create an effective definition of causation and really to understand when responsibility should be assigned. There are some gains, however, from this causal evisceration. Causal decision makers who follow the economic theorists are able to see potential causal relationships among factors that are 
obscured by Hart and Honoré's traditional causal framework. But these factors are outside the traditional framework precisely because they involve claims that are outside the moral framework of the causal inquiry. ${ }^{67}$ Cause exists for the economists only to the extent that they destroy the ability of the causal decision maker to appreciate causal questions.

67. For example, economists cannot explain how a court might find a parent guilty of child abuse and neglect and order his children taken from him, but not find the parent guilty of the same offense in criminal law. The reason for this distinction in treatment is that while the parent's actions may have caused the injuries to the children, they are often not intentional actions. Landes \& Posner have argued that we could and should eliminate the notion of intention from intentional tort and collapse tort analysis into an analysis of diminution of social welfare. Landes \& Posner, An Economic Theory of Intentional Torts, 1 INT'L REV. L. ECON. 127 (1981)

When legal concepts are collapsed into a single standard, there is some gain because courts and other causal decision makers are able to make their evaluations in a one-step analysis. There is also a loss, however, in the courts' ability to make individualized comparisons. For example, the parent in my hypothetical could in fact have contributed to the loss of social welfare by using the wrong standards to discipline a child and yet not be liable in criminal law (or in tort law to the child) because the parent's action lacked the requisite wrongful quality. Hart and Honoré's concepts of cause and condition are helpful in understanding such problems. The parent's actions caused the injury if they were both abnormal and voluntary. In reading those concepts into the question whether a parent is guilty of abuse and neglect, the court is asking whether the actions of the parent were, at least, conditions. In asking whether the parent ought to be punished, the court has to ask the additional question of whether the parent's actions were wrongful. When the notion of intention is eliminated, it is not possible to distinguish the second question from the first question. 